\title{
Correction: Disparities in NICU quality of care: a qualitative study of family and clinician accounts
}

\author{
Krista Sigurdson ${ }^{1,2,3} \cdot$ Christine Morton $^{4} \cdot$ Briana Mitchell $^{1,2} \cdot$ Jochen Profit ${ }^{1,2}$
}

Published online: 24 July 2018

(c) The Author(s) 2018. This article is published with open access

Correction to: Journal of Perinatology; https://doi.org/10. 1038/s41372-018-0057-3; published online 5 April 2018

The original HTML version of this Article incorrectly showed the copyright holder to be 'Nature America, Inc., part of Springer Nature', when the correct copyright holder is 'The Authors 2018'. This has been corrected in the HTML version of the Article. The PDF version was correct from the time of publication.

Open Access This article is licensed under a Creative Commons Attribution-NonCommercial-NoDerivatives 4.0 International License, which permits any non-commercial use, sharing, distribution and reproduction in any medium or format, as long as you give appropriate credit to the original author(s) and the source, and provide a link to the Creative Commons license. You do not have permission under this license to share adapted material derived from this article or parts of it. The images or other third party material in this article are included in the article's Creative Commons license, unless indicated otherwise in a credit line to the material. If material is not included in the article's Creative Commons license and your intended use is not permitted by statutory regulation or exceeds the permitted use, you will need to obtain permission directly from the copyright holder. To view a copy of this license, visit http://creativecommons.org/licenses/by-nc-nd/4.0/.

Krista Sigurdson

ksigurd@stanford.edu

1 Perinatal Epidemiology and Health Outcomes Research Unit, Division of Neonatology, Department of Pediatrics, Stanford University School of Medicine and Lucile Packard Children's Hospital, Palo Alto, CA, USA

2 California Perinatal Quality Care Collaborative, Palo Alto, CA, USA

3 Social and Behavioral Sciences, University of California, San Francisco, San Francisco, CA, USA

4 California Maternal Quality Care Collaborative, Palo Alto, CA, USA 